\title{
THE SEMANTICS OF THE SPANISH ADJECTIVE POSITIONS: A MATTER OF FOCUS
}

\author{
LOTTE DAM \\ Aalborg University \\ ld@cgs.aau.dk
}

\begin{abstract}
This paper presents a hypothesis about Spanish adjective position that accounts for different occurrences in language use. The hypothesis is based on the idea that the modifier position itself is a meaningful sign and that the meaning of the modifier position is related to focus: the postnominal modifier creates focus, whereas the prenominal modifier does not create focus. Drawing on the analysis of examples from a text corpus, the paper suggests that the proposed meaning of the two positions offers an account of various empirical phenomena. For example, it can explain why some adjectives are normally placed in one of the positions and why some adjectives change meaning according to their position.
\end{abstract}

Keywords: cognitive linguistics, focus, instructional semantics, Spanish adjective position

\section{Introduction}

It is a well-known fact that like other Romance languages, the attributive adjective in Spanish may appear after the noun (NA: noches calurosas, 'hot nights') or before the noun (AN: calurosas noches, 'hot nights'), and that post-position is the most common. Many scholars have already addressed this subject and offered useful insights. However, there is no clear consensus on the exact meaning of the two positions themselves, and not everyone ascribes meanings as such to the positions. Based on earlier insights, the aim of this paper is to advocate for a univocal meaning of the two adjective positions that can serve as a starting point for comprehending the use of adjective position in authentic language. ${ }^{1}$ The overall hypothesis is that the postnominal modifier position creates focus, whereas the prenominal modifier position does not create focus. The suggested meanings of the two positions predict various empirical phenomena, such as the fact that some adjective types "prefer" one position to the other or that some adjectives acquire a different meaning according to their position. The paper exemplifies the hypothesis through analyses of examples derived from a text corpus. ${ }^{2}$

1 Authentic language refers to written or spoken language used in real situations, in contast to data gained through introspection.

2 Unless stated otherwise, all examples are taken from CORPES, a database of the Real Academia Española, the official institution responsible for regulating the Spanish language. CORPES is a corpus of contemporary Spanish (2001-2012). 
The study is situated within instructional semantics. In this framework, meaning is conceived of as a mental representation that emerges when a linguistic input instructs the addressee to initiate an interpretive process. The two possible positions of the adjective in Spanish are seen as giving different instructions about focus.

\section{Instructional semantics}

Instructional semantics is based on a cognitive view in which meaning is constructed by individual interlocutors in an interpretive process. This cognitive view is inspired by well-known theories in the field of cognitive linguistics such as Fauconnier (1994), Johnson-Laird (1983), and Langacker (1987, 1991, and 2000). In an instructional semantics terminology, meaning is a mental representation initiated by instructions from language to an addressee. It follows that instructions constitute part of the meaning of linguistic items. The result of the interpretation is the establishment of meaning as output. The term meaning thus applies to different levels: it refers both to the semantics of linguistic items as input (the instructions) and to the result of the interpretive process as output. In this view, linguistic items are seen as contributing to the interpretive process in different ways depending on whether they are functional or lexical. Whereas lexical items offer instructions for the establishment of a mental representation of the concept that they themselves denote, functional items provide instructions for the interpretation of something distinct from themselves, typically lexemes. An important characteristic of a functional item is that it is univocal: it has one coded meaning (see Thrane 1997 and Thrane 1999). This does not mean, however, that its input cannot lead to different types of output. Linguistic input (the instructions) is combined with information from co-text and context to create meaning, and different final meanings can arise.

In accordance with the framework of instructional semantics, the position of the attributive adjective has a functional instructive meaning by virtue of its syntactic function as a modifier. The modifier provides instructions for the word that fills in the function, in many cases an adjective. This instruction is related to the notion of focus.

\section{Other accounts of Spanish adjective position}

At a more general level, the paper builds on insights provided by classical linguists such as Bello ([1847] 1988: 179), Ramsey ([1894] 1956: 665), and Salvá ([1931] 1988: 326). With small variations in the wording, they were agreed that an adjective placed before the noun is explicative: it presents a property that is inherent in the meaning of the noun itself. On the other hand, an adjective placed after the noun is specifying: it restricts a property that is not inherent and therefore 
has to be specified. This distinction was later applied by Alarcos Llorach (1994: 82). Nevertheless, it is the work carried out by Klein-Andreu (1983), Delbecque (1990), Fant (1990), Matte Bon (1995), and Nølke (1999) that lead more directly to the ideas presented in this paper. ${ }^{3}$ According to Klein-Andreu (1983: 150), the postnominal adjective signals contrast, whereas the prenominal adjective signals noncontrast. In the same vein, Fant (1990: 34) suggests that the postnominal adjective means 'look for a significant difference', whereas the prenominal adjective means 'Do not look for any significant difference'. Delbecque's study (1990) deals with both Spanish and French adjective position. She suggests that the variation NA and AN is a matter of focus adjustment and proposes a global analysis in terms of the figure/ground alignment. Similarly, in dealing with the position of the attributive adjective in French, Nølke (1999) suggests that focus is the most important factor in the choice of position. Matte Bon (1995: 185) suggests that the postnominal adjective composes new information about the noun, and that this leads to a larger accentuation of the adjective in this position, whereas the prenominal adjective is not new information.

Klein-Andreu (1983: 144) points out that many traditional treatments describe Spanish adjective placement as dependent on the adjective itself. This is also seen in later studies. In their chapter on adjective position, Butt and Benjamin (1988) build upon the basic rule that restrictive adjectives follow the noun, whereas nonrestrictive adjectives may precede or follow the noun (1988: 62). RAE (2009: Section 13.13 and 13.14) and Demonte (1999) provide very detailed expositions with a large number of relevant details about different adjective types and their position. In the present paper, it is suggested that the proper meanings of the two positions can explain these details. The paper starts from the idea of Bouchard (1998: 140) that it is not enough to establish a correlation between adjective types and their syntactic distribution (in French); a theory should provide some indication about the reason of the correlation between them. This will be explained in Section 6.

\section{Focus}

The topic of focus has been approached by researchers working in various linguistic paradigms, from functionalism (see, for example, Halliday 1967; Lambrecht 1994; Dik 1997; Givón 2001) to the government and binding framework (see, for example, Kiss 1998 and Drubig 2003). Also, as pointed out by Erteschik-Shir (2007: 27), focus has been defined in many ways and from several perspectives; semantic, phonological, syntactic, and pragmatic. ${ }^{4}$ Important

3 For a state of the art description, see for example Almela Pérez (2000: 294-295), and Whitley (2002: 231-236), although these are not completely new.

4 Erteschik-Shir (2007: 27-42) offers a survey of important contributions to focus from the several perspectives. See also Dufter and Jacob (2009b: 3-5). 
contributions to the field of focus in Romance language and/or specifically in Spanish are for example Dufter and Jacob (2009a), Dufter and Jacob (2009b), Leonetti and Escandell-Vidal (2009), Leonetti and Escandell-Vidal (2010), Manuel Leonetti (2011) and Ortega-Santos (2016). ${ }^{5}$ Ortega-Santos (2016: 1) argues that it is important to study focalization processes because (among other things) "it [the study of focalization] provides a unique perspective on the grammar and (a) the interaction of its various components (e.g., syntax, semantics and phonology), (b) its relation to linguistic (and non-linguistic) context, ..". Despite differences in the theoretical approach, the overall way of conceiving of the notion of focus in different approaches is similar. Focus involves highlighting, calling attention to, text elements. The notion falls within the area of information structure and has often been opposed to topic. In this sense, topic is related to given (presupposed) information in a sentence, whereas focus is related to new information about the topic. Therefore, focus answers relevant wh-questions (see, for example, Beaudrie 2005). As pointed out by Gundel (1999: 296), however, newness in relation to the topic is not the only reason for calling attention to a constituent. Another reason for calling attention to a constituent could be the intention to contrast it with something else. This has led to two distinct notions of focus in the literature, by Gundel (1999: 295-296) referred to as semantic focus and contrastive focus. Other terms used are information gap and contrast gap (Dik 1997: 331), presentational focus and contrastive focus (Drubig 2003: 2), and information focus and identificational focus (Kiss 1998: 245). The two interpretations of focus are not exactly the same for all scholars, but they are similar. In this paper, the terminology of Kiss (1998) will be used. According to Kiss (1998: 245),

An identificational focus represents a subset of the set of contextually or situationally given elements for which the predicate phrase can potentially hold; it is identified as the exhaustive subset of this set for which the predicate phrase actually holds

whereas

If a sentence part conveys new, nonpresupposed information marked by one or more pitch accents - without expressing exhaustive identification performed on a set of contextually or situationally given entities, it is not an identificational focus but a mere information focus (Kiss (1998: 246)

Sentences (1) and (2) illustrate information focus and identificational focus respectively:

(1) (¿Qué vas a comprar?) Voy a comprar unos pantalones.

'(What are you going to buy?) I'm going to buy a pair of trousers.'

5 Dufter and Jacob (2009b) e.g. provide a survey of early observations about focus in Romance language studies and of early theories about information structure. 
(2) No voy a comprar el jersey, solo los pantalones.

'I'm not going to buy the sweater, only the trousers.'

In (1), the noun phrase unos pantalones ('a pair of trousers') is introduced as a new constituent in the sentence that answers the wh-question about the topic. The constituent is not identified as an exhaustive subset of contextually or situationally given elements for which the predicate phrase can potentially hold. In (2), on the other hand, the constituent los pantalones ('the trousers') is identified as the exhaustive subset of the set of contextually or situationally given elements for which the predicate phrase can potentially hold. In this case, el jersey ('the sweater') and los pantalones ('the trousers') constitute the contextually given elements. The adverb solo ('only') brings out the noun phrase los pantalones as a constituent chosen among, in this case, two possible constituents in a buying situation. In this example, solo is a focalizer. The set consists of other possible elements from a paradigm to which the constituent belongs. In (2), the focalized constituent los pantalones is taken from a set consisting of members (the sweater and the trousers) of the paradigm CLOTHES CONSIDERED TO BUY. Whereas informational focus obviously cannot be on the topic in a sentence, identificational focus can. This has also been put forward in Nølke (2006: 72). It is due to the fact that the speaker may have other reasons for calling attention to a constituent than newness, such as contrasting (topic) elements in a sentence.

Kiss (1998), Drubig (2003), and Beaudrie (2005) suggest that identificational focus in different languages is subject to parametric variation: it allows a contrastive reading or an exhaustive reading. Focus is [+ contrastive] if a set consisting of a limited group of elements is known to the participants in the discourse (see example 2 and 3). In this case, the identification of a subset of the given set also identifies the contrasting complementary subset (Kiss 1998: 267). The focus is [+ exhaustive] (see example 4) if the set of entities is open. In this case, the identification of the subset does not result in the delineation of a complementary subset with clearly identifiable elements (Kiss 1998: 268). The following examples with the adverb solamente as a focalizer are inspired by Kiss (1998: 268):

(Me han dicho que has invitado a Juan y María.) - No, solamente he invitado a Juan.

'(I have been told that you have invited Juan and María.) - No, I have only invited Juan'.

(Me han dicho que has invitado a mucha gente.) - No, solamente he invitado a Juan.

'(I have been told that you have invited a lot of people.) - No, I have only invited Juan.'

In (3), the focalized element Juan is taken from a set consisting of specific members (two individuals called Juan and María), whereas in (4) the set does not consist of clearly identifiable elements, but is an open set of members. Blok and Eberle (1999) suggest the term alternative for elements that are left behind; in (3) the alternative is the person called María, and in (4) it is other people. The 
examples illustrate that the same sentence can give rise to different interpretations of alternatives according to the co-text/context.

Identificational focus can be created on the basis of lexical or functional elements. This gives rise to the terms lexical focalizers and functional focalizers. In (2) - (4), the adverbs solo and solamente are lexical focalizers. Examples of functional focalizers in Spanish are cleft sentences and explicit pronoun subjects (Spanish belongs to the pro-drop languages. This means that a sentence normally does not need an explicit subject, since the verbal morpheme marks the subject; implicit subject). ${ }^{6}$ Above, the notion of focus has been related to the sentential level. However, according to Nølke (2006: 76-77), there can also be a focus within a NP, i.e. at a lower level than that of the sentence. Nølke uses the terms major focus and minor focus, respectively. This idea will be elaborated in the next section.

(Identificational) focus is a widespread category in Spanish that is coded in various lexical and functional linguistic items. As maintained in this paper, focus is also related to adjective position in Spanish. It is suggested that the post-position of a modifier in Spanish is an example of a functional focalizing construction.

\section{Focus in the 'adjective-noun' and 'noun-adjective' patterns}

The various focalizers share a more abstract instructional meaning as they all instruct the addressee to establish a mental model in which something is highlighted. In addition to the more abstract instructional meaning, each focalizer has its own specific instructional meaning. With regard to Spanish adjective position, this additional meaning is related to the modifier function. It is the contention of this paper that an explanation of the two possible positions of the attributive adjective must be sought in the meaning of the modifier function itself, whether the function is provided by an adjective or by some other linguistic expression. Other types of linguistic material than adjectives can be used as modifiers, such as participles, prepositional phrases, and relative clauses. In addition to its functional meaning as a modifier, the attributive adjective has a descriptive meaning due to its status as a lexical word class. Different types of material provide different semantic nuances, but the functional meaning of the modifier is constant. This meaning is an instruction to an addressee to modify the part of a noun phrase that is within its scope with the meaning of the modifier. However, since the modifier function in Spanish takes two different positions, there must be an additional meaning. It is this meaning that can be found in the notion of focus. So, the post-position instructs the addressee to focus the adjective. The pre-position, on the other hand, instructs the addressee not to focus the

6 For more details and examples of focus constructions in Spanish, see Leonetti and EscandellVidal (2009; 2010), Leonetti (2011) and Ortega-Santos (2016). Ortega-Santos (2016: 17-81) provides the state of the art in research on focalization processes in Spanish. 
adjective. The suggested idea that the meanings of the two positions are always the same, clashes with a point made by Delbecque (1990: $369-370)$ :

the postponed adjective enters figure-status, which it shares with the noun it modifies; moreover, it stands out as focus. This last characteristic is not present when NA ordering is prototypical, since in the latter case the adjective occupies its natural position, and is, therefore, not likely to receive the focus of attention.

Post-position occurs most frequently and it is the unmarked form (RAE 2009: 990) in spite of the fact that this position is the one endowed with a specific meaning. In other words, it can be argued that this is a case where focus is related to an unmarked form. This could be explained by the fact that the attributive adjective is a modifier. The basic function of a modifier is to provide more information about an entity. ${ }^{7}$ The suggested instructional meanings ascribed to the two positions enter as an underlying explanation of the examples in this paper in interplay with co- and context in each concrete example.

In the examples of focus provided in Section 4, the focused constituents are constructed by NPs, whereas the focused constituents in relation to adjective position are constructed by modifiers. In other words, the focalized constituent is a subconstituent in a NP and therefore has a different status in the whole sentence than a NP. As pointed out in Section 4, Nølke (2006: 76 - 77) distinguishes between major and minor focus. He suggests that NPs constitute scopes of minor focus. This means that in addition to the major focus in a whole sentence, there can be a minor focus within a NP. This is illustrated in (5) - (6).

(5) La puerta del patio se abre y aparece [una mujer con un VESTIDO [BLANCOFoc] FocINF. NA $^{8,9}$ 'The door into the yard opens and a woman in a white dress appears.'

(6) Aunque el alimento elegido puede variar mucho de mujer a mujer, la mayoría prefiere [los ALIMENTOS [DULCES $]_{\text {FOC }}$ antes que los [salados $\left.]_{\text {FOC }}\right]_{\text {FOCINF. NA }}$

'Although the chosen food can vary a lot from one woman to another, the majority prefers sweet food to salty food.'

According to Nølke (1999: 109; 2006: 77), postnominal adjectives in French are focalized alone or together with the noun. In $(5)-(6)$ the adjectives are focalized alone AND together with the noun and other elements. There is information focus within the whole sentence, and the postnominal adjectives have minor focus

7 Leonetti and Escandell-Vidal (2009; 2010) and Leonetti (2011) relate fronting of constituents with focus. Nevertheless, they do not treat the position of modifiers/adjectives, but full NPs. Therefore, I will not compare their claims with mine.

8 The abbreviations 'NA' and 'AN' are used at the end of each example to indicate the internal order between the noun and the adjective in the specific examples.

$9 \quad$ The analyzed noun phrases are in small caps. 
within the NP's. ${ }^{10}$ This is due to its function as a modifier. ${ }^{11}$ In (5), the focus on blanco ('white') is information focus, i.e. the same as the full NP. The full NP as a whole is new to the addressee, but, in addition, inside the NP the adjective has a specifying function as a modifier that only concerns the noun and makes it more possible to identity the dress. It is more precise to say 'white dress' than only 'dress'. In Section 4, it was indicated that only identificational focus represents a subset of contextually or situationally given elements. This is not the case within the NP vestido blanco ('white dress') as the dress is not highlighted between other dresses or clothes. However, I will argue that because of the paradigmatic and specifying nature of modifiers, also when the adjective forms part of an information focus, other alternatives are present, just in a more indirect way. If it is specified that a dress is white, this is because it could have had another color as well. In other words, 'white' is chosen from the paradigm COLORS.

In (6) the whole phrase los alimentos dulces antes que los salados ('sweet food to salty food') has information focus, but in addition, los alimentos dulces ('sweet food') is contrasted to los salados ('salty food'), that is identificational focus [+ contrastive]. From the illustrations [DULCES $]_{F O C}$ and $[S A L A D O S]_{\mathrm{FoC}}$ it seems that focus only extends to the adjectives, which is not the case, as it is the entities denoted by the full nouns which are identified as subsets of a set consisting of the two members, which are now known to the participants in the discourse, and contrasted to each other. However, the focus stems from the instruction from the position of the adjectives, which is illustrated in this way. ${ }^{12}$ What happens is that identificational focus always extends over the full NP. As Kiss (1998: 248) points out, identificational focus can never be a subconstituent. In (6), the entity food is the same in the contrasted elements, and the meaning of the adjective is what constructs the subset. According to Nølke (2006: 65), focus is the result of an interpretation that takes place in the moment of utterance. In (6), other inputs for the interpretation than the one of focus are the verb preferir ('to prefer') and the presence of antes que los salados ('to salty food'). The inputs together lead to the result of the interpretation (the output), which is identificational focus with [+ contrastive]. In (7), the same interpretation as in (6) is possible.

\section{María Sofía se puso el VESTIDO ROSA. NA}

'María Sofía put on the pink dress.'

This interpretation is activated if a set of various dresses are present in the domain of discourse, and the pink one is chosen among this set. However, it is also possible that the set in the domain of discourse consists of different types of

10 "Sweet food" and "salty food" have not been mentioned in the previous text and is therefore new to the addressee.

11 As the topic of this paper is the position of the adjective, I will not address other possible focus constituents in the sentences.

12 In the second element, the noun is not expressed in the Spanish example, but it is semantically implied. 
clothing, such as the pink dress and a green skirt. In this case, the interpretation would be that the pink dressed was chosen rather than the green skirt. In this case, the full NPs construct the subset because the types of entities are different. Consequently, the result of the interpretation of the same sentence can be different in different contexts, as in (7). According to the hypothesis put forward, the input from the postnominal adjective is an instruction to the addressee to modify the noun and focalize the lexical meaning of the adjective. This input, which is always the same, interacts with other input in the sentence in question. In the interpretation of (7), the co-text does not suffice. In this case, it is necessary to know the context to achieve the final meaning; that is whether the alternatives are other dresses or other clothing.

According to Nølke (1999: 109; 2006: 77), prenominal adjectives in French are either not focalized (8) or are focalized together with the noun (9). This idea is illustrated in the following Spanish examples:

(8) Este LARGO AMOR con Willie ha sido un regalo en los años maduros de mi existencia. AN 'This long-lasting love with Willie has been a gift in the mature years of my life.'

(9) Bueno, la verdad es que me siento un poco cansada esta noche, Richard. Ha sido [un LARGO DÍA $]_{F O C}$ y tengo mucho en qué pensar. AN

'The thing is that I feel rather tired tonight, Richard. It has been a long day and I have had a lot to think about.'

In (8), the NP is not focalized. The instruction not to focus it means that there is no minor focus within the NP. The long-lasting love is already known to the participants and it is the topic of the sentence. In (9), the prenominal adjective is not focalized by its position either, but it forms part of the focalized NP (information focus) as a subconstituent. In both (5) and (9), the full NP is focalized, but whereas in (5), the adjective is focalized with the aim of specifying, i.e. providing additional information about the referent of the NP to make it easier to identify it, in (9) a reason for not focalizing the adjective could be because the property is expected.

The prenominal position is an obvious choice when the adjective denotes a property that is already known to the addressee, because, in many cases, there is no need to highlight the property. In (10) the adjective blanca describes an inherent property as is forms part of the intension of the lexeme NIEVE and is therefore already known to the addressee.

\footnotetext{
Pero alrededor solo veían la BLANCA NIEVE. AN

'But all they could see around them was the white snow.
}

blanca ('white') forms part of information focus together with the noun, but the instruction not to focus it means that there is no minor focus within the NP. Nevertheless, the inherent property for some reason is extracted from the noun. This gives as output a static description evoking a snow-covered landscape. 
Adjectives in postnominal position that describes an inherent property do, however, occur:

(11) Abrió la puerta de la cocina y salió al patio casi ciega por la NIEVE BLANCA. NA

'She opened the door to the kitchen and went into the yard almost blinded by the white snow.

(12) La reina contempló el contraste de LA SANGRE ROJA sobre LA NIEVE BLANCA y suspiró. ${ }^{13} \mathrm{NA}$, NA

'The queen contemplated the contrast presented by the red blood on the white snow and sighed.'

In (11) depicts a change of state in the subject because of the whiteness of the snow. This causal relation established by means of the preposition por ('by') would still hold without the adjective, as the property of whites of snow is already known. Adding and focusing blanca ('white') creates a contrast between the outside luminosity and the relative darkness inside the house. In (12), the reason for focusing the adjectives is to create contrastive focus on the NPs: the white snow is contrasted to the red blood ([+ contrastive $]$ ).

Sometimes the output resulting from the instruction from the prenominal positioning is the interpretation of a common feature of a whole group:

(13) Quizá por ello, y por las LARGAS DISCUSIONES que mantuvimos en esa época, Uriarte me ha ya pedido que escriba esta recensión. AN

(14) 'Perhaps because of that and because of the long discussions that we had at the time, Uriarte has asked me to write this review.'

The prenominal position of largas prevents the possible interpretation of a subset consisting of long discussions contrasted to another one consisting of short discussion (identificational [+ contrastive] focus). This interpretation would be possible if the adjective was focused. Thereby the addressee is indirectly told that the individuals' discussions were generally long. However, the adjective can also be found in postnominal position without major difference (15):

(15) Quizá por ello, y por las DISCUSIONES LARGAS que mantuvimos en esa época, Uriarte me ha ya pedido que escriba esta recensión. NA

'Perhaps because of that and because of the long discussions that we had at the time, Uriarte has asked me to write this review.'

(15) is a constructed example to illustrate that there is not always a major difference between pre-and postnominal position. In (15), contrast to specific short discussions is not created either. Instead, what the postnominal adjective does is to highlight the property of length, only indirectly opposing it to shortness.

13 This example stems from a Spanish translation of Snow White and the Seven Dwarfs. 


\section{The relation between adjective position and adjective type}

The innate semantics of some adjectives affects its suitability for prenominal or postnominal position. For example, some adjectives are always (or almost always) in postnominal position, whereas others are common in both positions. The focus hypothesis will also provide the basis for an explanation of the group of adjectives that normally change meaning according to their position.

\subsection{Specific adjectives and general adjectives}

A common distinction is often made between relational adjectives, such as industrial ('industrial') and cubano ('Cuban'), and qualitative adjectives, such as grande ('big') and redondo ('round') (see, for example, Demonte 1999: 137- 139 and RAE 2009: 914), but depending on the topic, other distinctions are also relevant. It is the contention of this paper that the distinctive feature, that is relevant to adjective position and focus is specificity. This idea is inspired by Nølke (1999). Adjectives contain minimal semantic features called sems, which are more or less specific. Depending on the sems, adjectives can be classified as specific adjectives or general adjectives, but they can also contain both types of sems. Specific adjectives have a precise meaning, independent of the nouns that they modify, whereas the meaning of general adjectives is less precise and depends on the meaning of the nouns that they modify. This distinction is more or less equivalent to the distinction between categorematic and syncategorematic adjectives (see, for example, Delbecque, 1990), and the distinction between intersective adjectives and non-intersectives adjectives (see, for example, Demonte 1999: 144, and RAE 2009: 925). Relational adjectives are specific as they denote a specific class to which a noun belongs. Examples are nuclear ('nuclear'), agrícola ('agricultural'), irlandés ('Irish') and musulmán ('Muslim'). Among the qualitative adjectives are both specific adjectives, such as triangular ('triangular') and amarillo ('yellow') and general adjectives, such as bueno ('good') and grande ('big'). The focus hypothesis predicts the following:

- Adjectives with very specific sems tend to be found in postnominal position because their meaning makes them adequate for specifying or classifying an entity. They have a strong distinctive force.

- In prenominal position, adjectives with specific sems lose the sems, have their sems weakened, or lose their distinctive force.

- Adjectives with few specific sems or none often occur in prenominal position.

- Adjectives with general sems gain specific sems or gain distinctive force in postnominal position. 


\subsubsection{Specific adjectives}

The normal position of relational adjectives is the postnominal one as in (16) (19).

(16) Además estalló la CRISIS ECONÓMICA. NA

'Moreover, the economic crisis started.'

(17) Aparte de la facilidad para llegar nos ha interesado su SITUACIÓN GEOGRÁFICA. NA

'Apart from the access, we are interested in its geographical location.'

(18) ¿Cree que es elegante la MUJER ESPAÑOLA? 'Do you think that Spanish women are elegant?' NA

(19) Nos asesoran en la PRODUCCIÓN INDUSTRIAL. NA

'They advise us with regard to industrial production.'

In spite of their specific sems, adjectives that denote geography (20) and religion (21) sometimes do occur in prenominal position:

(20) ... aunque también esperaba conseguir el carné de manera fácil y, de paso, evitar a mi regreso EL MUY ESPAÑOL TRANCE DE ESTUDIAR COMO UN OPOSITOR, SUSPENDER COMO UN RETRASADO Y PAGAR COMO UN MILLONARIO... AN - AN

'Although I also hoped to get my driver's license in an easy way and at the same time avoid reverting to the very Spanish trait of studying like a maniac, failing like a retarded person, and paying like a millionaire.'

(21) Y algunos años después su CATÓLICA ESPOSA lo sorprende fumando a escondidas en su casa de Ayamonte. ${ }^{14}$ AN

'And a few years later his Catholic wife surprises him smoking secretly in their house in Ayamonte.'

In (20) and (21), the adjectives lose pure relational meaning and gain some qualitative meaning. As Delbecque (1990: 378) points out, "when a normally postponed adjective appears in prenominal position, it takes on the AN ordering"; it is [...] interpreted as though it were an adjective of another class. Demonte (1999: 151) and $\operatorname{RAE}$ (2009: 988) refer to this phenomenon as recategorization. In (20), the presence of the adverb of degree muy implies a variation between "more or less" which is not compatible with a meaning of pure relation (as in for example un pasaporte español, 'a Spanish passport'). What is meant here is that studying like a maniac etc. is very common behavior in Spain. Likewise, in (21), the meaning of religious affiliation is strongly reduced; instead, the adjective involves connotations of properties related to Catholicism: more specifically, it involves austerity, which makes it worse that the individual in question is discovered smoking. Examples like these have a subjective tone and often, as pointed out by RAE (2009: 988), an ironic ring. It is, however, also possible to

14 This example was found in the predecessor of Corpus del Español del Siglo XXI (CORPES), CREA. Corpus de referencia del español actual. 
establish a qualitative meaning with a postponed adjective; the difference is that if the adjective is preponed, it happens for sure.

\subsubsection{General adjectives}

The behavior of general adjectives is not precisely opposite to the way in which specific adjectives behave. General adjectives commonly occur in both positions. The most common general adjectives are bueno, malo, grande and pequeño, which are all qualitative. Just as some specific adjectives can lose a specific feature when they are placed out of focus, general adjectives can gain a specific feature when they are placed in focus position. This is partly in agreement with Demonte (1999: 198), who suggests that a group of Spanish adjectives uses the two positions to distinguish an intersective meaning from a non-intersective meaning. ${ }^{15}$ Demonte (1999: 199) illustrates her point with the following examples:

(22) Gran jefe - Jefe grande AN, NA

'Great boss' - 'big/large boss'

(23) Buen amigo - Amigo bueno AN, NA

'Good friend' - 'Good friend'

In (22), the meaning of grande in prenominal position depends on the noun and is "big" in the sense of "great", i.e. the person is great as a boss. By way of contrast, grande in the postnominal position does not depend on the noun so specifically, but on the general class to which the boss belongs, that is a big/large person. In the same vein, in (23), bueno in prenominal position means "good as a friend", whereas in postnominal position bueno means "a good person". It is, however, important to mention that these are default meanings. The following authentic examples with co-text illustrate the meanings described by Demonte.

(24) Todo a la salud de tu padre, que es un GRAN JEFE. AN

'All the best to your father's health; he is a great boss.'

(25) El Ministro no es un cualquiera, es un jefe, un JEFE GRANDE del Partido, y él vino a hablarnos, a nosotros, pobres campesinos. NA

'The Minister is not just anyone; he is the big boss from the Party, and he came to talk to us, to us, the poor farmers.'

(26) Qué simpatico que era Herrera. Y un BUEN AMIGO, además. AN

'Herrera was so sweet. And a good friend too.'

(27) Mi abuela también decía: "un AMIGO BUENO y fuerte, llega más allá de la muerte”. NA

'My grandmother used to say: a good and strong friend outlives death.'

15 Among her examples are verdadero, bueno, grande, nuevo, pobre, viejo, raro y real. In this paper, however, a distinction is made within this group between general adjectives whose more precise meaning depends on a noun, and adjectives whose meaning is more or less fixed by their position. The adjectives in this group are cierto, nuevo, viejo, antiguo and pobre. This group is discussed in the next section. 
The different interpretations can be explained on the basis of the focus hypothesis: when the adjective is in postnominal position and thereby in focus position, it gains a specific sem and enhances a more precise meaning which is not dependent on the specific meaning of the noun. By way of contrast, the prenominal adjective does not have this sem and acquires its more precise meaning from the noun in question. Examples (28) to (31) illustrate the same phenomenon:

(28) Trae en la mano derecha una MALETA PEQUEÑA. NA

'He has a small suitcase in his right hand'.

(29) La chica entró en una HABITACIÓN GRANDE. NA

'The girl entered a big room.'

(30) ... me comentaba el sábado un empresario de origen paquistaní pero pasaporte británico que tiene un PEQUEÑO NEGOCIO y se gana bien la vida. AN

'Last Saturday, a Pakistani businessman with a British Passport told me that he has a small business and that he earns well.'

(31) Su obra obtuvo una GRAN RESONANCIA en los años setenta. AN

'His work attained great resonance in the 1970s.'

The meaning of the postnominal pequeño and grande is specific as they refer to physical magnitude (the meaning is concrete), whereas the prenominal adjectives do not have these specific features; instead, they have a metaphorical meaning defined by the noun. These meanings may not exclusively stem from position, as they are obviously also in agreement with the nouns. The corpus also contains examples of a general adjective with a more concrete and specific meaning in prenominal position $(32-33)$, just as there are examples of general adjectives with a metaphorical meaning in postnominal position $(34-35)$ :

(32) El padre de Bradman se ganaba la vida como carpintero en un PEQUEÑO PUEBLO de Nueva Gales del Sur, a unos cien kilómetros de Sydney. AN

'Bradman's father earned his living as a carpenter in a small village in New South Wales, about a $100 \mathrm{~km}$ from Sidney.'

(33) El joven que nos acompañaba nos abrió camino hasta una GRAN HABITACIÓN llena de mesas en deorden. AN

'The young man who accompanied us showed us into a big room full of tables which had been left pell-mell.'

(34) Ob viamente es difícil predecir cuándo un PROBLEMA PEQUEÑo es señal de algo grande. NA 'It is obviously difficult to tell when a small problem is a sign of something bigger.'

(35) Y es que Pipe para esa época era un HOMBRE GRANDE dentro del mundo del narcotráfico. NA

'And this is because Pipe was a big man in the world of drug smuggling at the time.'

In (32) and (33), pequeño and grande can only be understood in a concrete, specific way due to the co-text. In (32), the noun pueblo can only be small in a concrete way. In isolation, gran habitación (33) could be understood as an impressive room, but here the rest of the noun phrase rules out this understanding. The reason for placing the adjective in prenominal position in (32) is probably not to emphasize the property of being small: it is an inherent or at least expected 
property of a village to be small. In (33), one possible explanation is similar: it is expected that a room can be big. Another possibility is that the speaker does not want to emphasize the magnitude, as there is another property that he or she wishes to emphasize - in this case, that the room was untidy. In (34), pequeño is not interpreted as 'little' in a physical way because of the noun problema. In this example, no specific sem is gained; instead the focus position is used to create a contrast between pequeño and grande later in the sentence. In (35), grande is understood metaphorically. In this example, the speaker wishes to emphasize Pipe's importance. The various examples show that the final meaning is a result of the interplay between the instructions implied by the positions and the cotext and context, for example, the meaning of the adjective and noun. This illustrates a crucial point put forward by Klein-Andreu (1983: passim): different meanings of the adjectives are just different interpretations of a single meaning in different contextual conditions.

\subsection{Adjectives with two meanings}

Spanish grammars normally describe a special group of adjectives whose meanings are said to change according to their position before or after a noun. The adjectives listed are not exactly the same in every grammar book, but the following are often mentioned: nuevo (in postnominal position: 'brand-new', in prenominal position: "recently-arrived"), antiguo (in postnominal position: 'old/antique/ancient', in prenominal position: "former/previous"), distinto (in postnominal position: 'different', in prenominal position: "several/another"), cierto (in postnominal position: 'certain; sure/true', in prenominal position: "particular; certain/one"), puro (in postnominal position: 'clean', in prenominal position: "sheer") and pobre (in postnominal position: 'poor; not rich', in prenominal position: "poor; miserable”). According to Nølke (1999: 155 - 156), this phenomenon in French can also be explained in terms of the relation between focus and sems. In postnominal position, these adjectives "keep" their specific sems, whereas they lose them in prenominal position: ${ }^{16}$

(36) Montando una CASA NUEVA estaba resultando una tarea más absorbente de lo que había calculado. NA

'Building a new house turned out to be a much more demanding job that anticipated.

(37) El NUEVo ALUMNO parecía, efectivamente, un par de años mayor que el resto de los muchachos. AN

'As a matter of fact, the new student looked a couple of years older than the rest of the kids.

Estábamos en otro planeta. Un UNIVERSO DISTINTO nos acogía. NA

'We were in another planet. A different universe welcomed us.'

16 The use of the phrasing 'to keep sems' is based on the fact that post-position, as earlier stated, is the unmarked position. 
(39) En los DISTINTOS GRUPOS DE DISCUSIÓN, los padres participantes aparecieron muy sensibles al problema del consumo juvenil de drogas. AN

'In the different discussion groups, the parents who participated were very sensitive with respect to the problem of the consumption of drugs among youngster.' ${ }^{17}$

The postnominal nuevo, for example, has a classifying value in (36) which is opposed to the meaning of "old", whereas the prenominal nuevo has a temporal value in (37) and is thus in opposition to "earlier". It is only in (36) that nuevo classifies the noun as such, i.e. ascribes a proper quality to it. Another example is distinto in postnominal position, which means that something has other properties than something else (38). This is a classifying meaning, whereas its meaning in prenominal position is 'another' (39), that is, a type of temporal value. Another example is pobre. Nølke (1999: 156) suggests a semantic analysis of the French equivalent pauvre. According to this analysis, it is possible that pauvre contains a general sem that indicates a situation of absence and another more specific sem that indicates that the object of absence is material. This is the key to the meaning of pauvre/pobre in prenominal position: the adjective loses the specific sem and contains only the general sem of absence. The meaning of pobre in prenominal position can be derived from this: un pobre hombre ('a poor man') is a man who is without something (friends, love, health, work etc.). This meaning can be considered as an affective meaning.

(40) Aumentará la deuda de los PAísES POBRES. NA

'The debt in poor countries will increase.'

(41) El POBRE HOMBRE dice que ha sido visitado por una santa. AN

'The poor man says that a saint has been to see him.'

Nuevo and antiguo can be explained in the same way: they may contain a more general sem of novelty and a more specific sem that indicates date. The adjectives in this group lose their qualitative meaning in prenominal position. However, in line with the idea put forward by Klein-Andreu (1983: passim), that the different meanings of these adjectives are just different interpretations, the two different meanings of these adjectives are not fixed lexical a priori meanings, but interpretations of a single meaning in different contextual conditions. In the words of Klein-Andreu (1983: 167), "Yet, here again, it is simply not true that antiguo means 'former' in pronominal position, and 'old' in postnominal postion". It is more that the meanings of the two positions favor a certain meaning. In (42), for example, the meaning of the postnominal nuevo is the temporal meaning, that is, the meaning normally associated with the prenominal position:

${ }^{17}$ It is worth mentioning that it is more frequent to find the plural form of distinto in prenominal position because of its meaning. 
(42) Miré por primera vez la casa con su farmacia antigua en los bajos y sí, ese lugar de color avellana era el HOGAR NUEVO. NA

'I saw, for the first time, the house with the old pharmacy in the ground floor, and, yes, this hazel-colored place was the new home.'

The speaker in this example uses the focus position with another aim - to highlight that the home is in fact his or her home now. Again, the different examples illustrate that the final meaning results from the interplay between the instructions derived from the position, on the one hand, and, on the other, the co-text and context.

\section{Concluding remarks}

The analysis of the examples presented in this paper supports the idea of a univocal meaning of the two adjective positions. It also supports the idea that the meaning of the positions can be explained with appeal to focus. There is a basic principle in linguistics: before suggesting new meanings or functions, one should look for what already exists. If a meaning or function already exists in a language or across languages, it is very possible that it plays a role in other linguistic elements. Focus is a category that can be identified in various linguistic words and constructions in Spanish. It is coded, not only lexically, but also structurally. The analysis of different examples has illustrated that this notion (+/- focus) functions as a univocal meaning of the two adjective positions that is able to explain various empirical phenomena in language use, such as the tendency of specific adjective types to appear in one or the other of the two possible positions.

\section{References}

Alarcos Llorach, Emilio. 1994. Gramática de la lengua española. Madrid: Espasa Calpe.

Almela Pérez, Ramón. 2000. El orden AS / SA: la solución está en el conflicto. In Gerd Wotjak (ed.), En torno al sustantivo y adjetivo en el español actual. Aspectos cognitivos, semánticos, (morfo)sintácticos y lexicogenéticos (Lingüística Iberoamericana 11), 293-309. Madrid: Iberoamericana.

Beaudrie, Sara. 2005. Refinando la noción de foco en español: Cuestiones semánticas y sintácticas. Arizona Working Papers in Second Language Acquisition and Teaching 12. 21-30.

Bello, Andrés. [1847] 1981. Gramática de la lengua castellana destinada al uso de los americanos (Edición crítica de Ramón Trujillo). Santa Cruz de Tenerife: Instituto Universitario de Lingüística Andrés Bello.

Blok, Peter I. and Kurt Eberle. 1999. What Is the Alternative? The Computation of Focus Alternatives from Lexical and Sortal Information. In: Peter Bosch and Rob van der Sandt (eds.), Focus: Linguistic, Cognitive, and Computational Perspectives, 105-120. Cambridge: Cambridge University Press.

Bouchard, Denis. 1998. The distribution and Interpretation of adjectives in French: A consequence of Bare Phrase Structure. Probus 10: 139-183. 
Delbecque, Nicole. 1990. Word order as a reflection of alternate conceptual construals in French and Spanish. Similarities and divergences in adjective position. Cognitive Linguistics 1. 349416.

Demonte, Violeta. 1999. El adjetivo: Clases y usos. La posición del adjetivo en el sintagma nominal. In Ignacio Bosque and Violeta Demonte (ed.), Gramática descriptiva de la lengua española 1 , 129-215. Madrid: Espasa Calpe.

Dik, Simon. 1997. The Theory of Functional Grammar. Part I: The Structure of the Clause. Berlin, New York: Mouton de Gruyter.

Drubig, H. Bernard. 2003. Toward a typology of focus and focus constructions. Linguistics 41(1). $1-50$.

Dufter, Andreas and Daniel Jacob. (eds.) 2009a. Focus and Background in Romance Languages. Amsterdam/Philadelphia: John Benjamin Publishing Company.

Dufter, Andreas and Daniel Jacob. 2009b. Introduction. In Andreas Dufter and Daniel Jacob (eds.), Focus and Background in Romance Languages, 1-18. Amsterdam/Philadelphia: John Benjamin Publishing Company.

Erteschik-Shir, Nomi. 2007. Information Structure. The Syntax-Discourse Interface. Oxford: Oxford University Press.

Fant, Lars. 1990. On the Relevance of the Semantics/Pragmatics Distinction. CEBAL/Copenhagen Studies in Language 13. 16-40.

Givón, Talmy. 2001. Syntax 1. Amsterdam: John Benjamins Publishing Company.

Fauconnier, Gilles. 1994. Mental spaces. Cambridge: Cambridge University Press.

Gundel, Jeanette K. 1999. On Different Kinds of Focus. In Peter Bosch and Rob van der Sandt (eds.), Focus: Linguistic, Cognitive, and Computational Perspectives, 293-305. Cambridge: Cambridge University Press

Halliday, M. A. K. 1967. Notes on transitivity and theme in English. Part 2. Journal of Linguistics 3. 199-244.

Johnson-Laird, Philip N. 1983. Mental Models. Cambridge: Cambridge University Press.

Kiss, Katalín E. 1998. Identificational Focus versus Information Focus. Language 74(2). 245-273.

Klein-Andreu, Flora. 1983. Grammar in Style: Spanish Adjective Placement. In: Klein-Andreu, Flora (ed.), Discourse Perspectives on Syntax, 143-179. New York: Academic Press.

Lambrecht, Knud. 1994. Information structure and sentence form: topic, focus and the mental representation of discourse referents. Cambridge: Cambridge University Press.

Langacker, Ronald. W. 1987. Foundations of Cognitive Grammar 1. Theoretical Prerequisites. Stanford: Stanford University Press.

Langacker, Ronald W. 1991. Foundations of Cognitive Grammar II. Descriptive Application. Stanford: Stanford University Press.

Langacker, Ronald. 2000. Why a mind is necessary. Conceptualization, grammar and linguistic semantics. In Liliana Albertazzi (ed.), Meaning and Cognition, 25-38. Amsterdam: John Benjamins Publishing Company.

Leonetti, Manuel. 2011. La expresión de la estructura informativa en la sintaxis: un parámetro de variación en las lenguas romáticas. Romanistisches Jahrbuch 61. 338-355.

Leonetti, Manuel and Victoria Escandell-Vidal. 2009. Fronting and verum focus in Spanish. In: Andreas Dufter and Daniel Jacob (eds.), Focus and Background in Romance Languages, 155204. Amsterdam/Philadelphia: John Benjamin Publishing Company.

Leonetti, Manuel and Victoria Escandell-Vidal. 2010. Las anteposiciones inductoras de foco de polaridad. In: Víctor M. Castel and Liliana Cubo de Severino (eds.), La renovación de la palabra en el bicentenario de la Argentina Los colores de la mirada lingüística, 733-743. Mendoza: Editorial de la Facultad de Filosofía y Letras de la Universidad Nacional de Cuyo.

Matte Bon, Francisco (1995). Gramática Comunicativa del español. De la lengua a la idea. Madrid: Edelsa.

Nølke, Henning. 2006. La focalisation: une approche énonciative. In: Hélène Wlodarczyk and André Wlodarczyk, La focalisation dans les langues, 59-80. Paris: L'Harmattan. 
Nølke, Henning. 1999. Det franske sprog. Kapitel V, II. Modifikation 2. Copenhagen: CBS.

Ortega-Santos, Iván. 2016. Focus-related Operations at the Right Edge in Spanish. Amsterdam/Philadelphia: John Benjamin Publishing Company.

Ramsey, Marathon Montrose. ([1894] 1956. A Textbook of Modern Spanish. New York: Henry Holt and Company.

Real Academia Española (RAE) (2009): Nueva gramática de la lengua española I. Madrid: Espasa Libros.

Salvá, Vicente. [1931] 1988. Gramática de la lengua castellana (estudio y edición de M. Lliteras) 1. Madrid: Arco Libros.

Thrane, Torben. 1997. Understanding semantics. In: Carl Bache and Alex Klinge (eds.), Sounds, structures and senses. Essays presented to Niels Davidsen-Nielsen on the occasion of his sixtieth birthday, 235-250. Odense: Odense University Press.

Thrane, Torben. 1999. Understanding functionality. Unpublished paper.

Whitley, Stanley M. (2002). Spanish/English Contrasts. A Course in Spanish Linguistics. Washington D.C.: Georgetown University Press.

Corpora

Real Academia Española: Corpus del Español del Siglo XXI (CORPES).

Available at: http://web.frl.es/CORPES/view/inicioExterno.view

Real Academia Española: Corpus de referencia del español actual (CREA).

Available at: http://corpus.rae.es/creanet.html 